\title{
Determinants of Economic Empowerment and Women's Roles Transfer
}

\section{Faktor-Faktor Pemberdayaan Ekonomi dan Alih Peran Perempuan}

\author{
Amiruddin Saleh ${ }^{1, *)}$, Ana Kuswanti², Alyssa Nahla Amir ${ }^{3}$, Rita Nur Suhaeti ${ }^{4}$ \\ ${ }^{1}$ Head of Research Center for Human Resources Development, IPB University, Bogor 116801, Indonesia \\ ${ }^{2}$ Pembangunan Nasional Veteran University, Jakarta, 12450, Indonesia \\ ${ }^{3}$ Brandenburgische Technische Universität, Cottbus 03046, Germany \\ ${ }^{4}$ Research Center for Human Resources Development, IPB University, Bogor 116801, Indonesia \\ ${ }^{*}$ Corresponding author: amiruddin_ipb@yahoo.co.id
}

Diterima: 4 November 2021 | Disetujui: 16 Februari 2021 | Publikasi Online: 24 Februari 2022

\begin{abstract}
Women, who were members of Economic Empowerment of Women Headed Family (WHF) Group and married in marital status, still tend to have lower economic status. There was a social reality that roles and functions of husbands and wives in many communities had shifted, especially of WHF Group members in Batang District, Central Java Province. The crucial condition causing the mentioned shifting was economic factors. Formerly, wives were only supporting bread winners, however, because of family economic needs, women switched their roles into breadwinners. Wives also took action as dominant decision makers in their households, although society had not fully recognized woman's participation in development communication as head of family. The newest finding in this research was that married women, whose husbands had been fired, had already been included into WHF Program. There was 45 percent of WHF Group members, who still got married to husbands with no permanent jobs, and 15 percent belonged to those whose husbands had got fired, and five percent was jobless. The results of FGD supported the finding that there were some married women that had shifted from supporting breadwinners into main breadwinners.
\end{abstract}

Keywords: Economic empowerment, role shifting, women

\section{ABSTRAK}

Perempuan berstatus menikah pada anggota kelompok Pekka masih cenderung memiliki taraf ekonomi rendah. Realitas pada masyarakat telah terjadi pergeseran fungsi dan peran terhadap suami dan istri khususnya pada kelompok Pekka di Batang Jawa Tengah. Keadaan krusial yang menjadikan perubahan tersebut adalah karena faktor ekonomi. Suami mengalami perubahan status sosial, yang semula bekerja, karena terjadi pengurangan massal karyawan atau pegawai, suami mengalami pemutusan hubungan kerja (PHK). Semula istri hanya sebagai pendukung dalam mencari nafkah, namun karena keterbatasan ekonomi keluarga, perempuan beralih peran menjadi pencari nafkah utama. Perempuan bersuami juga mengalami alih peran menjadi pengambil keputusan dominan dalam rumah tangga, namun keterlibatan perempuan dalam komunikasi partisipasi pembangunan belum diakui secara utuh oleh masyarakat sebagai Pekka. Temuan terbaru dalam penelitian adalah perempuan bersuami masuk dalam kategori Pekka karena suami tidak memiliki pekerjaan tetap, suami mengalami PHK, suami menganggur. Terdapat 45 persen anggota Pekka dari kategori bersuami, suami tidak memiliki pekerjaan tetap, 15 persen suami mengalami PHK dan lima persen menganggur, kondisi tidak permanen. Berdasarkan hasil FGD memperkuat temuan penelitian, bahwa terdapat beberapa perempuan yang masih berstatus bersuami beralih peran dalam menunjang perekonomian keluarga sebagai pencari nafkah utama.

Kata kunci: Alih peran, pemberdayaan ekonomi, perempuan

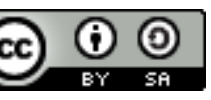

Content from this work may be used under the terms of the Creative Commons Attribution-ShareAlike

4.0 International. Any further distribution of this work must maintain attribution to the author(s) and the title of the work, journal citation and DOI.

Published under Department of Communication and Community Development Science, IPB University and in association with Perhimpunan Ahli Penyuluhan Pembangunan Indonesia.

E-ISSN: 2442-4110 | P-ISSN: 1858-2664 


\section{INTRODUCTION}

The Economic Empowerment of Women Headed Family (WHF) Program was one of the solutions to deal with the sore economic times. Empowerment was carried out through a non-formal education called "Paradigta." Education and training were expected to develop woman's talents and skills, in this case, through literacy education, bookkeeping, entrepreneurship, journalism, public speaking, and negotiating lobbies.

Literacy education was intended for WHF members, who were illiterate and could not read properly. Bookkeeping was taught in order that women would be able to prepare financial reports, so that they would be able to manage a business, such as a savings and loan cooperative. The entrepreneurship training included a variety of entrepreneurship skills training, such as catering, fashion, make-up, cultivation, and grocery shop business. The journalism skill training included writing skill, which was started by telling their own condition, making reports, articles, or bulletins. The public speaking training enabled women to speak before forums in general, such as in discussions, meetings, seminars, workshops and in training activities. Mardikanto (2010) mentioned that many villages encouraged women's empowerment, boosted women to get more income and enjoy several public facilities provided by the village government, which contributed to improving woman's health status.

Education was carried out to develop not only managerial talent, but also mental strengthening as a basis for woman's psychological strengthening. Before joining the WHF group, women usually experienced mental disorders as a result of being widows, getting divorced or victims of domestic violences that made them depressed and helpless. Moreover, there was a negative society's stigma towards widows. In general, women did not have economic readiness after being left by their husbands (e.g because initially they were served only as home makers) so that when they were separated from their husbands, they were unprepared, weak, helpless, and they had to get a job to survive.

Economic empowerment for women through communication activities supported woman's selfsufficiency as heads of families, and also solved issues of women's empowerment. Katjasungkana in the discussion of the National Development Strategy Formulating Team (Nugroho, 2008) stated that there were four indicators of empowerment: (1) Access, in the sense of equal rights in accessing productive resources in the environment; (2) Participation, namely participation in utilizing these limited assets or resources; (3) Control, namely that men and women have equal opportunities to exercise control over the use of these resources; and (4) Benefits, namely that men and women must equally enjoy the results of the use of resources or development together and equally. It was in line with the research results of (Yuniriyanti \& Sudarwati, 2017) that women were designed as role models for empowerment in improving family food security efforts.

Economic empowerment could be carried out through five aspects of the community empowerment approach, namely: Enabling, Strengthening, Protecting, Supporting and Maintaining (Suharto, 2009). (1) Enabling was to create an atmosphere or climate allowing community potential to develop optimally. Empowerment must give cultural and structural barrier free that hindered the community. (2) Strengthening was to strengthen community's knowledge and abilities in solving problems and meeting their needs. Empowerment must be able to develop all the abilities and self-confidence of the poor that support their self-sufficiencies. (3) Protection was to protect the community, especially weak groups from being oppressed by strong ones. Empowerment must be directed at eliminating all types of discriminations and dominations that did not benefit the poor. (4) Supporting was to provide mentoring and support so that the poor were able to carry out their roles and life tasks. Empowerment must be able to support the poor so that they do not fall into conditions and positions that are increasingly weak and marginalized. (5) Maintaining was to maintain conducive conditions in order to maintain a balanced power distribution between various groups in the society. Empowerment must be able to ensure harmony and balanced opportunity that allows everyone to do business.

The mentioned above explanations provided the meaning that community economic empowerment is an effort to build power by encouraging, motivating, and raising awareness of their own potential. Needs assessment, exploring and utilizing existing resources are needed so that the community would be able to fulfil their needs and achieve a prosperous life. Community economic empowerment was strengthening production factors, ownership, strengthening distribution and marketing control, strengthening communities to get adequate wages/salaries, and strengthening communities to obtain information, knowledge and skills. The community empowerment must be carried out in multi- 
aspects, including its own community aspects as well as policy aspects. According to the stated above concept, the economic empowerment of women in the WHF groups required an approach of enabling, strengthening, protecting, supporting and maintaining. It is important to support deeper awareness to build impetus, motivation, in improving the economy through policies, opening access (through increasing human resource access) namely woman economic empowerment in groups. Based on the explanation above, this study aims to: (1) determine the factors in economic empowerment, and (2) analyze the effect of the characteristics of WHF group members on Economic Empowerment.

The research applied post-positivism paradigm, a quantitative approach, which was strengthened by qualitative analysis. The research applied a survey method, and the research location was Batang District, Central Java Province. Stratified Random Sampling or Layered Random Sampling was applied for sampling technique, using village as stratum so that there were 12 strata. The number of samples obtained using the slovin formula was 229 WHF members. The study was conducted from March to December 2019.

\section{METHODOLOGY}

This research uses the post-positivist paradigm, with a quantitative approach reinforced by qualitative analysis. The research method combines quantitative and qualitative methods, so the study's data will be more valid because data that cannot be validated by quantitative methods will be validated using qualitative methods, and vice versa. In the post-positivism paradigm, the purpose of research is to predict results, test a theory, or find the strength of relationships between variables or a cause and effect relationship. The post-positivism paradigm assumes that humans cannot always correct in seeing a reality. Therefore, triangulation method is needed to collect various sources of data and information. Inside this paradigm the relationship between the observer and the object must be interactive. However, the observer here must be neutral so that the level of subjectivity can be reduced. Typical methodologies include designs that are experimental, quasi-experimental, correlational, causal comparative, quantitative and randomized control trials research. Data gathering instruments include questionnaires, observations, experiments and tests. The post-positivism paradigm believes more in the verification process of a finding using various methods. Therefore, researchers applied this paradigm for this study.

This research utilized a survey method in Batang, Central Java. The survey design used methods by testing research hypotheses to explain the relationship between variables. Furthermore, the researcher designed the survey by combining explanatory research with descriptive research. Information was collected from 229 respondents using a questionnaire. The study was conducted for 10 months, starting in March 2019. Research population were female household heads, who were active members of WHF Groups. The total population of WHF members in Batang District were 535 person, who lived in twelve villages, namely Botolalang Village, Wringin Village, Sambojo Village, Wringin Gintung Village, Siberuk Village, Wonokerso Village, Jrakah Payung Village, Tegalsari Village, Bakalan Village, Juragan Village, Cempereng Village, and Beji Village).

Stratified Random Sampling or Layered Random Sampling was applied for sampling technique, using village as stratum so that there were 12 strata. Scheaffer et al. (2011) mentioned that a layered random sample is a sample obtained by dividing the population into several non-overlapping groups, and then took the sample randomly from each group. These groups were called layers or strata. It was assumed that the characteristics of WHF members in each village were non-homogeneous; therefore, the village was the basis of the strata in making conclusions in this study. The number of samples obtained using the slovin formula was 229 WHF members.

The qualitative data was obtained using the Focused Group Discussion (FGD) technique on eight respondents. The data analysis technique used descriptive statistical analysis (frequency, percentage, median, mean and total mean score), and inferential statistical analysis, namely the structural equation model (SEM) with the LISREL program.

\section{RESULTS AND DISCUSSION}

\section{Characteristic Factors of WHF Group Members}

Characteristics of WHF members is presented in Figure 1. The characteristics of WHF respondents consisted of age, education, marital status, number of dependents, and income. The research results 
showed varying results. Respondents owned different characteristics of age, education, marital status, number of dependents and income.
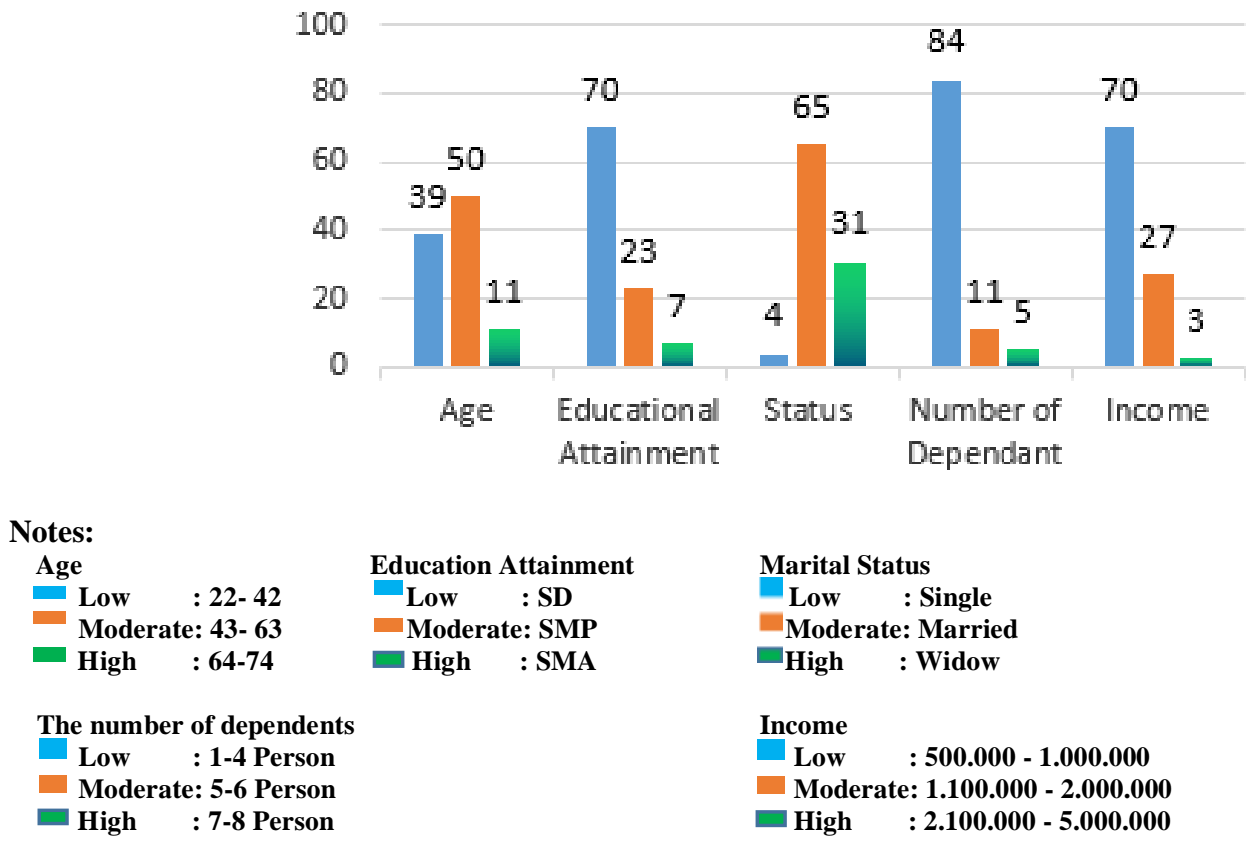

Fig. 1. Characteristic factors of WHF group members, Batang, Central Jawa

Age. Age of 50\% respondents ranged between 43 and 63 years. It was followed by 39 percent of respondents' age, which ranged between 22-42 years, and the other 11 percent showed the age range of 64-74 years. The WHF members, whose age range of 22-63 years worked as farmers, farm laborers, traders, household assistants, factory workers, and they worked to fulfil family needs, to support husbands as well as main breadwinners. More productive age was at the age of 22-42 years. They were younger, more agile, more skilled, and more creative in developing the acquired skills. It was also supported by their strong physical condition.

Educational Attainment. Most WHF members (70\%) owned low educational attainment, some of whom were only on elementary school (SD) and $23 \%$ owned moderate educational attainment or Junior High School (SMP) and the other 7\% owned higher educational attainment or Junior High School (SMA). None of the WHF members went to university. Based on the results of the FGD, they think that education was not a priority for WHF members. It is important for women to change their mindset to move forward, namely by placing the mindset in their lives that higher education was needed, because higher education will let them be empowered (Nagaraja, 2018). Low literacy rates gave a negative impact on women's lives and also on their families and the country's economic and social development (KunhiSikhaBhuyan, 2020).

Marital Status. Most WHF members still got married, and their husbands gave permission to join their husbands in the WHF group (65\%). There were 31\% of WHF members, four percent of whom were were widows and unmarried WHF members. For some reasons, there were some married WHF members, shifted their roles to be dominant decision makers and as the main breadwinners in the families.

Number of Dependents. Most WHF group members (84\%) got few dependents (1-4 persons). The WHF members, who owned moderate dependent number (5-6 persons) was $11 \%$ and the other 5\% of WHF members had large number of dependents (7-8 persons). Having few dependents in the family was a good thing, so that they were able to fulfil all the needs for their families, and it was in accordance to their earned income.

Income. Most WHF group members (70\%) belonged to low level income (IDR 500,000$1,000,000 /$ month), while members, who belonged to medium level income (IDR 1,100,000$2,000,000 /$ month) was $27 \%$, and the other three percent of WHF group member belonged to high level income (IDR 2,100,000-5,000,000/month). The income earned by the WHF group members was in accordance with standard of living in Batang area, Central Java. 


\section{Factors of WHF Group Members Shifted Their Roles}

It has already known that $65 \%$ of the WHF group members still got married. Usually, women played supporting role to the breadwinners (husbands); however, when their husbands could not play their roles properly (45\% got impermanent jobs, $15 \%$ got fired and 5\% jobless) then women played roles as breadwinners. The research results was presented in Figure 2.

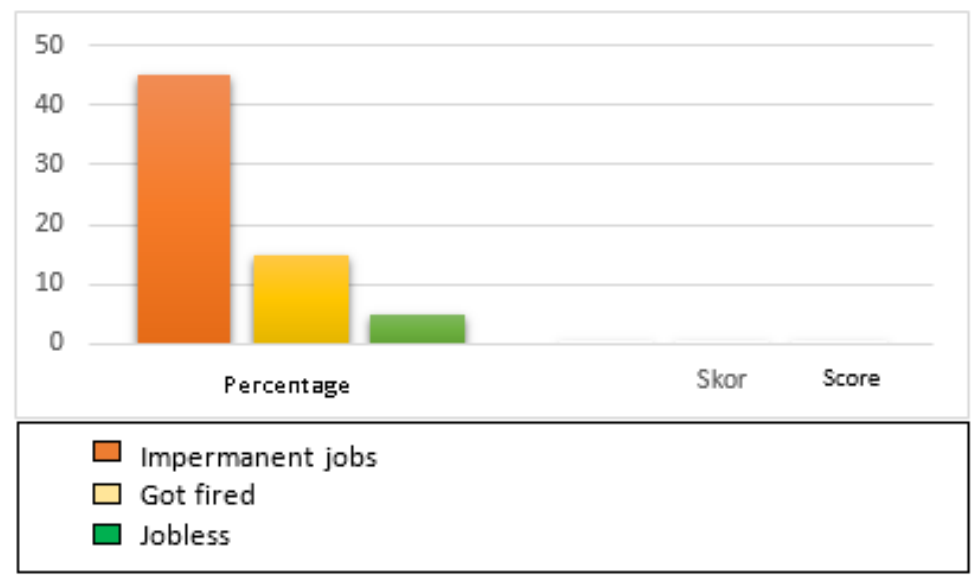

Fig. 2. Factors of WHF group members shifted their roles

The research results revealed that women had a very important position in shifting their roles for the sake of family's survival. It was in line with Shireesha in, Kuswanti et al, (2020), who mentioned that in India, the whole development of the country depended on 50\% of the population. The half of the population means women, who were not fully empowered due to social and cultural limitations such as social taboos. Therefore, Government of India had initiated so many schemes for Women Empowerment.

According to FGD results, the situation was impermanent. It could be changed at any time, because sometimes the husbands earned enough income for a long time; however, it was possible that at other times the husbands got impermanent jobs so that the income would decrease. The condition of the jobless husband was also impermanent. Usually, it did not take long for the husband to get another job. The findings of this study revealed that married WHF members sometimes to change roles, and it was also impermanent and it could be accepted by each husband and wife with great understanding. Married women were also the dominant decision makers in the family, where household affairs were fully the responsibility of the wife, although in a patriarchal society and socio-culturally, the role of women as heads of families were not fully recognized. It was in line with Shabanirad \& Seifi (2014), that if there was still a patriarchal culture, then women would be still marginalized and oppressed.

According to the Act of Population Administration 2006, women could be legally and formally being a head of a household. In line with Kuswanti et al. (2020a), women's role had been dominant, although it often encountered problems in its implementation. Furthermore, Kuswanti et al. (2020b) explained that it was important to empower women through feminization of some partisan aspects and offered new opportunities for women's representation in parliament. Women's empowerment in Bangladesh had achieved success, however, woman's role of women in politics did not guarantee that their rights could be fulfilled (Hasan \& Alim, 2014). Ghazanfari-Moghaddam \& Sharifimoghaddam (2014) mentioned that women were able to work, and their works were accepted by readers, and were able to encourage cultural change.

\section{Factors on WHF's Economic Empowerment}

Table 1 revealed that score average of each economic empowerment indicator varied. Indicator on capital access gained the highest score, but the lowest on managerial skills. More detailed indicator order were as the following: the access to capital gained the highest average score of 2.67 , followed by risk management indicators 2.57, business assistance indicators 2.52, and the lowest score on managerial skills with an average score of 2.39. The average total score on the variables of economic empowerment of theWHF group had been assessed as good with an average total score of 2.53. 
Access on capital for WHF members could be obtained through savings and loans cooperative and revolving business capital subsidy. The debts were jointly managed by WHF members. The FGD results that within the WHF group, access to capital and mentoring had been carried out well; however, the abilities and skills possessed by WHF members were still limited to compete in public.

WHF members admitted that provided access on capital had been able to increase their income. Managerial skill was still needed to be improved, because it was still in the bad category. It was an interesting finding, considering that the access to business mentoring had already been in good category. The risk management had also been in the good category, and WHF members were able to analyze and minimize risks in creating a business. The results were presented in Table 1.

Table 1. Distribution of score average on WHF members' economic empowerment variables

\begin{tabular}{lc}
\multicolumn{1}{c}{ Economic Empowerment Variable } & Score Average* \\
\hline Access on capital & 2,67 \\
Business guidance & 2,52 \\
Managerial skills & 2,39 \\
Risk management & 2,57 \\
\hline Total & 2,53 \\
\hline Notes: *Very bad: 1-1,75; Bad: 1,76-2,51; Good: 2,52-3,27; Very good: 3,28-4 &
\end{tabular}

Based on the results of the FGD related to access to capital, it was known that:

“..We usually start with IDR 500,000 for a micro business start up. So far it was still going on. We continued to strive for continuous coaching and revolving capital assistance and we could identify what was profitable for self-employed business would be continued and pushed to be more self-sufficient."

In line with this, WHF members also said in the FGD meeting that they have been carrying out entrepreneurial activities for several years and have been provided with capital by WHF, and until now they are still continuing.

"I had been in WHF for six years. Initially, I used to be diligent to take part in training and then I was offered some business capital, until now I am still continuing. I also plan to start a rice trading business earlier this month (November 2019). I am also used to the activities that I live, I could make time for my family and keep my entrepreneurship going on. I want the other members to be like me."

The FGD results showed that within the WHF group, access to capital and mentoring had been carried out well; however, the abilities and skills possessed by WHF members were still in limitation to compete in the public. WHF members admitted that the access to capital provided had been able to increase their income. The access to capital provided could also help increase the WHF members' confidence, because they tried to think about all risks by applying the various knowledge and skills they had received during joining WHF groups.

Latifah and Mulyana (2017) mentioned that through cooperatives, women could apply savings and loans with a joint responsibility system, so that they were able to capture business opportunities more quickly. Kuswanti et al. (2020a) mentioned that women played a dominant role in economy. This changed the tradition where women were only limited to domestic activities. Reality in the field showed that WHF members, who had limited access to capital have found a solution by providing revolving loans. For members, whose businesses had progressed and developed, could gradually be able to help other members. Caring for other members according to the facts in the field, they had high empathy, so they took care and helped each other in developing the businesses. The results of research on access to capital were the highest indicator in supporting WHF's economic empowerment. The average score obtained was 2.67, and it is considered good. Empowerment of WHF members to be able to realize economic independence is based on access to capital, in this case the mentors stated that there were several forms of empowerment that had been carried out so far. The results of research related to access to capital had the highest score. This means that access to capital was needed to carry out business activities in order to become empowered in economy. Activities to support business through savings and loans, social gathering, and training was a basis for developing skills in order to be empowered. 
The results of the study were in line with (Hasin \& Musa, 2018) that woman's empowerment encountered many challenges in overcoming the contours of life in society, so that it was necessary to apply a strategic model of women's empowerment. Therefore, to make women more empowered required a multidimensional process, which allowed women to increase self-confidence, personality and strength in all areas of life.

\section{Effect of WHF Member's Characteristics on Economic Empowerment}

Results of the goodness of fit test showed that by applying the chi square test, the conclusion is pvalue $0.03054<0.05$, so Ho is rejected and $\mathrm{H} 1$ is accepted. It means that the resulting model is not good enough; however, we can still see other goodness of fit, because the chi square is influenced by data and models. In addition, SEM provided an alternative to apply other goodness of fit indicators. The RMSEA criterion produced a value of $0.076 \leq .08$, which meant that the resulting model is within the goodness of fit.

The use of other goodness of fit criteria, namely GFI, NFI and CFI, produced a value $>0.9$, which meant that the resulting model has been already within goodness of fit. Because the conclusions of several indicators resulted in the conclusion of the goodness of fit model, then theoretical hypothesis testing could be carried out. WHF's economic empowerment described the empowerment of women heads of household as a manifestation of the training and knowledge that had been gained during joining the WHF group including economic empowerment through indicators of access to capital, business mentoring, managerial skill and risk management. The analysis applied in the study to determine the factors that significantly affected economic empowerment was SEM analysis. The results were presented in Table 2.

Table 2. Results of Processing and Test on SEM model Goodness of fit

\begin{tabular}{cccc}
\multicolumn{1}{c}{ Goodness-of-Fit } & Cutt-off-Value & Score & Conclusion \\
\hline$x^{2}$ - chi square & Expected to be small & 13,92 & Not Fit \\
Significance & $\geq 0,05$ & $\mathrm{p}=0,031$ & \\
RMSEA & $\leq 0,08$ & 0,076 & Fit \\
GFI & Approaching 1 & 0,990 & Fit \\
NFI & Approaching 1 & 1,000 & Fit \\
CFI & Approaching 1 & 1,000 & Fit \\
\hline Notes: RMSEA = Root Mean Square Error of Approximation; & & \\
CFI = Comparative Fit Index; GFI = Goodness of Fit Index; & & \\
IFI = Incremental Fit Index; NFI (Normed Fit Index) & & \\
\end{tabular}

Figure 3. showed that there were four indicators supporting the characteristics of WHF members. The most dominant percentage value was education indicator of 0.90 , followed by age indicator of 0.68 , income indicator of 0.44 , and the last indicator family dependents with the lowest percentage of 0.31 . It was in accordance with the results of the average score of economic empowerment and access to capital, which gave the highest indicator results by contributing the most in encouraging the characteristics variable of WHF members. Age and income were directly related to the number of dependents, as WHF members have fewer dependents, so with relatively small incomes they were still able to fulfil their living needs in accordance with the standard of living in the Batang area, Central Java. 


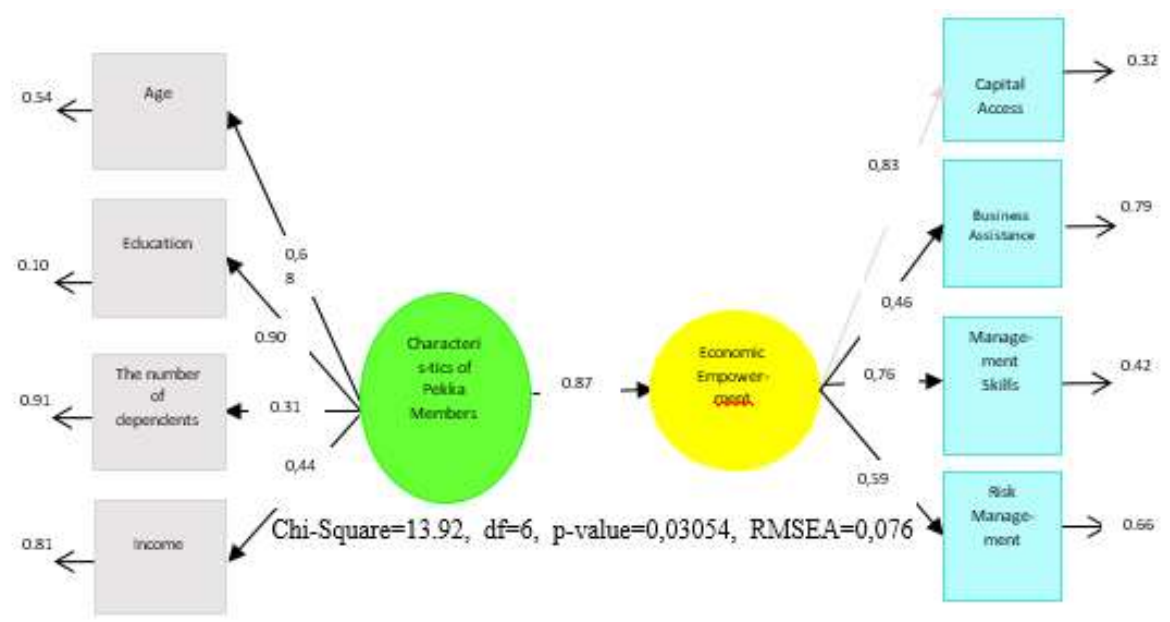

Fig. 3. Estimated loading factors of woman family heads characteristics affecting on 's economic empowerment

Determination magnitude of the highest value on the dependent variables of economic empowerment were four indicators with a percentage of 0.83 each on the capital access indicator, followed by the skill management indicator of 0.76 , the risk management indicator of 0.59 , and the last indicator on business mentoring of 0,46 . It was in line with the results on the average score, which showed that access on capital was the indicator that gave the highest contribution in encouraging economic empowerment variables. Access to capital could be obtained through savings and loans cooperative, and debts were jointly managed by WHF members, and revolving business capital subsidy. Economic empowerment within the WHF group was still being carried out. The results are presented in Figure 3.

Characteristics of WHF members $(\eta 1)$ gave a direct positive effect on economic empowerment $(\eta 3)$. Data analysis showed that an estimated coefficient of 0.87 was obtained, which means that the higher the characteristics of WHF members, the higher the direct economic empowerment and vice versa. These results indicated that the proposed theoretical hypothesis was proven by a statistical value of $7.24>\mathrm{t}$-table 1.96 meaning that Ho was rejected so that it can be concluded that there is a positive effect of the characteristics of WHF members $(\eta 1)$ on economic empowerment $(\eta 3)$. The results are presented in Table 3.

Table 3. Hypothesis theory test

\begin{tabular}{lcccc}
\multicolumn{1}{c}{ Path } & Estimate & S.E. & $\mid \mathbf{t}_{\text {-value }}>\mathbf{1 . 9 6}$ & Conclusion \\
\hline & Direct & & & \\
WHF members' characteristics $\rightarrow$ Economic & 0,87 & 0,12 & 7,24 & Significant \\
empowerment & & & & \\
\hline
\end{tabular}

Notes: significant at $\mathrm{p}<0,05$, $\mathrm{t}_{\text {-value }}>\mathrm{t}_{\text {-table }}(1,96)$

The SEM analysis consisted of latent variable, namely characteristics of WHF members with the following indicators: age, educational attainment, number of dependents and income; latent variable of WHF group characteristics with indicators: access on information, group roles, management roles, cadre roles and mentor roles; and latent variable of group participatory communication with indicators: ability to express ideas, dialogue, intensity of communication, direction of communication, problem solving methods and leadership roles. The better the characteristics of the WHF group could give a direct effect on the economic empowerment of the WHF, as well as the group's participatory communication, the better the participatory communication of the WHF group could give a direct positive effect on economic empowerment. On the other hand, the characteristics of WHF members, which were lacking (age, educational attainment, number of dependents and income) could give an indirect effect on economic empowerment and the results are presented in Table 4. 
Table 4. Decomposition results of effect of influencing factors on WHF economic empowerment $(n=229)$

\begin{tabular}{lccc}
\multicolumn{1}{c}{ Variables } & Direct Effect & Indirect Effect & Total Effect \\
\hline WHF Economic empowerment $(\eta 3)$ & & & \\
$\mathrm{R}^{2=} 0,013$ & $0,260^{* *}$ & $-0,030^{*}$ & $0,023^{*}$ \\
1. WHF members' characteristics $(\eta 1)$ & $0,066^{* *}$ & $0,020^{*}$ & $0,086^{*}$ \\
2. WHF group's characteristics $(\zeta 1)$ & $0,290^{* *}$ & - & $0,290^{* *}$ \\
\hline 3. Group's participatory communication $(\eta 2)$ &
\end{tabular}

Notes: significant at $\mathrm{p}<0,05$, $\mathrm{t}_{\text {-value }}>\mathrm{t}$-table $(1,96), \mathrm{R}^{2}$ : Effect

The results obtained indicated that the characteristics of WHF members, the characteristics of the WHF group, and participatory communication directly influenced on economic empowerment, respectively. Characteristics of WHF members had an indirect negative influence on economic empowerment. The characteristics of the WHF group had an indirect positive influence on economic empowerment. The results of the effect decomposition described in detailed in Table 4. It showed that the factors that directly and indirectly affected the latent variables of economic empowerment were as follows:

Direct effect. Direct effect of $\eta 1$ WHF members' characteristics on $\eta 3$ economic empowerment: $\eta 1 \rightarrow$ $\eta 3$ with beta coefficient of $\left(0,260^{*}\right) 2(p<0,05)$ means that the latent variable economic empowerment was directly explained $\left(0,260^{*}\right) 2$ or $6,76 \%$ by the latent variable of WHF members' characteristics.

Direct effect of $\zeta 1$ Pengaruh on $\eta 3$ economic empowerment: $\zeta 1 \rightarrow \eta 3$ with beta coefficient of $\left(0,066^{*}\right) 2(\mathrm{p}<0,05)$ means that the latent variable economic empowerment was directly explained $\left(0,066^{*}\right) 2$ or $0,43 \%$ by the latent variable of WHF groups' characteristics.

Direct effect of $\eta 2$ group's participatory communication on $\eta 3$ economic empowerment: $\eta 2 \rightarrow \eta 3$ with beta coefficient $\left(0,240^{*}\right) 2(\mathrm{p}<0,05)$ means that the latent variable economic empowerment was directly explained $(0,290 *) 2$ or $8,41 \%$ by the latent variable of WHF groups' characteristics.

Indirect effect. Indirect effect of $\eta 1$ WHF groups' characteristics on $\eta 3$ economic empowerment: $\eta 1$ $\rightarrow \eta 3$ with beta coefficient of $\left(-0,030^{*}\right) 2 \quad(\mathrm{p}<0,05)$ meant that the latent variable economic empowerment was indirectly explained $(-0,030 *) 2$ or $0,09 \%$ by the latent variable of WHF groups' characteristics.

Indirect effect of $\zeta 1$ WHF groups' characteristics on $\eta 3$ economic empowerment: $\zeta 1 \rightarrow \eta 3$ with beta coefficient of $(0,020 *) 2(\mathrm{p}<0,05)$ meant that the latent variable economic empowerment was indirectly explained $\left(0,020^{*}\right) 2$ or $0,04 \%$ by the latent variable of WHF groups' characteristics.

The results of the SEM analysis also shows that the latent variable of WHF members characteristics had an indirect negative effect on economic empowerment. The characteristics of WHF members consisted of age, educational attainment, number of dependents and income would reduce economic empowerment indirectly and vice versa. In order to empower the WHF members, who were economically empowered, participatory communication activities by further increasing ideas, dialogue, intensity discussion, direction of communication, ways of solving problems and leadership roles was needed to be carried.

Indirect effects occurred in accordance to the field findings, indirect economic empowerment could be realized through the WHF members' characteristics, which were indirectly influenced by participatory communication. Group participatory communication encouraged the WHF members to get used to getting trained in expressing ideas in WHF's activity forums (such as somethings related to agreement for time and readiness to implement training activities, cooperative development to get accessed on capital, savings and loans, and other shared problems in groups).

Participation provided inputs as solutions on various group and individual problems in order to find the best solution, thus to make Pekka members as women, who were able to show critical power, creative power, and who got more skilled and also more confident to appear before the forum. It was a manifestation that the characteristics of WHF members could not be separated from the participation of the group's participatory communication in encouraging the creation of economic empowerment. According to (Sultana et al., 2017), the condition of women with microfinance was more influential on knowledge and social empowerment than economic empowerment. The impact of microfinance was highly valued in providing confidence, courage, skill development and empowerment.

The indirect influence in the research is also seen through the characteristics of the WHF groups, which had an indirect positive effect on economic empowerment. The indirect effect of the WHF's 
group characteristics on economic empowerment can be realized through participatory communication. Findings in the field showed that the characteristics of WHF groups can encourage the implementation of participatory communication in groups, namely through more targeted activities such as the availability of access on information (WiFi is available at the WHF center), the role of groups, the role of administrators, the role of cadres and the role of facilitators. The availability of access to information encouraged training on how to access and use internet media. Women head family group members were given training on how to download, find and improve more accurate information from reliable sources such as sources (KPPA, WHF's website, legislative decisions, and others) related to women's empowerment. Pachaiyappen (2014) mentioned that it was important for women to be literate and able to access information properly.

Access on capital was facilitated through cooperatives, savings and loans, and joint debt responsibility. The goal was to encourage the implementation of economic improvement by fulfilling the necessities of life (fulfillment of basic needs for clothing, food and shelter), to be able to have a productive business (starting a self employed entrepreneurship even though it was still at a micro level such as mushroom cultivation, making various kinds of chips, opening a grocery shop, salon service business, sewing). It was a step to fulfil the economic needs, courage in making decisions such as having the courage to take debts and being able to pay in installments to repair houses, home loans, premaculture / renting agricultural land to improve economic status. The activities that had been carried out started from ideas, the occurrence of dialogue in meetings of of group members, administrators, cadres and assistants, quality discussion intensity and focus on problem solving, clear communication directions to overcome problems, both faced by members and the group in general.

Woman's empowerment programs were offered through; (1) Strengthening organization of woman's groups at all levels from village to national, with the aim to increase the capacity of institutions so that they could play an active role as planners, implementers, and controllers; (2) Increasing the function and role of woman's organizations in social marketing of empowerment programs. It is important, considering that so far the existing empowerment programs have not been socialized and have less involvement in the communit. (3) Involving woman's groups in planning. The involvement of women included physical development programs, strengthening the economy, and improving human resource quality; (4) Improving woman's leadership abilities, so that they would have an equal bargaining position, access and opportunities to be involved in development; and (5) Improving the ability of woman's group members in the business sector (small/home industry scale to large industrial scale) with various supporting skills such as production capabilities, business management capabilities as well as ability to access credit and wider marketing (Nugroho, 2008).

Programs to empower women heads of household to increase income could be conducted through handicraft training, business development, skills training, and education. The role of the WHF program for WHF participants through the existence of independent business capital loans to increase craft productivity could add side work in doing business in groups. The WHF programs could increase the income of WHF participants (Kuswanti et al., 2020b). Increasing human resources meant women become potential in line to opinion of (Kuswanti \& Oktarina, 2019) with the positive use of communication technology information media for housewives. It is very helpful in developing skills, so that they develop into independent businesses that can improve the family economy. Empowerment by maximizing access on information, in addition to increasing knowledge and insight, was also useful for facilitating the marketing of entrepreneurial products produced.

Empowerment efforts would build power by encouraging, motivating, and raising awareness of the potential. It had something to do with strengthening the potential possessed by the community. Assistances provided for skill development empowering women through WHF groups was not always in the form of financial support. Assistances were more for skills development in the form of savings and loans, education, training, to legal protection (Kuswanti et al., 2020b). The purpose of empowerment referred to the circumstances or results to be achieved by a social change, namely an empowered community. Having the power or knowledge and ability to fulfil the needs of life, whether physical, economic, or social, such as self-confidence. Finally it was expected that women would be able to express aspirations, have a livelihood, participate in social activities and be independent in carrying out their life tasks (Suharto, 2009).

Bhatia and Singh (2019) mentioned that India government provided inclusive financial services. It was an affordable financial service for all, and it had become a basic priority for many. The use of the Pradhan Mantri Jan Dhan Yojana (PMJDY) Scheme was quite successful, especially for women in 
slum areas and gave a positive influence on the social, political, and economic dimensions of woman's economic empowerment.

According to Istiyanto and Nuryanti (2013), there were two independent economic businesses, which were able to generate additional income for the family and economic empowerment results of the woman's empowerment. Respect for husband's position in the family was still a very strong thought in woman's mind. In line with the research findings, more than half of WHF's members were housewives but mostly dominantly supporting family economy. The participation of WHF group members to support their families just to carry out their obligations as good and devoted wives. The participation of women needs to be included in fostering an inclusive peace-building strategy. A rights-based commitment to gender equality was the foundation on which culturally literate empowerment strategies could be fostered (Porter, 2013).

WHF empowerment through economic aspect had been able to be realized with the various skills possessed by WHF group members. Various training such as public speaking skills (let them be able to provide assistance to help take care of problems with the police, religious courts, identity cards, and health insurance/BPJS), make-up, catering, lobbying and negotiation were conducted for them. Jobs in the service sector certainly let them earn income, which could support the increase in the family's economic status. WHF groups paid attention to women heads of household to be empowered. Through empowerment programs carried out by WHF groups, women were strengthened to be more independent, work or have businesses that could generate income to fulfil the needs of their families. According to (Winther et al., 2018) Indian women were relatively powerless and they enjoyed somewhat lower status than men did, despite many efforts made by the government. However, there were still bad facts about the low level of educational attainment, and sexual harassment.

Wediawati and Setiawati (2015) stated that the success of the plan and implementation of activities brought positive changes for Kube-WHF women in thinking frugally (priority scale), maintaining the quality of business products, creating new business products, being able to market products widely, and making Kube as macro finance, new business, being able to market products widely, and making Kube as macro finance. Implementation of WHF training activities had brought positive changes for WHF group members to get more empowered. It was also expected that women would be able to upload, and develop the potential they possessed, which encouraged family's economic improvement.

The Agaseke project played an important role in women socio-economic development. By providing various supports for women, especially for the poor, the Agaseke Project enabled women to become entrepreneurs. The results are consistent with the research, that WHF play an important role in socioeconomic development, with all facilities for training and education programs, enabling WHF to become more empowered, both mentally and economically. Plurality and willingness to experiment creatively with ways of communicating about listening and learning, and engaging in dialogue itself could be a catalyst for the change (Cornwall, 2016).

Communication model for empowering women farmers in the agropolitan areas of Pesawaran was a communication model for empowerment with democratic leadership and communication for empowerment with professional assistants; these two empowerment models provided a wide space for women farmers to contribute to their efforts in farmer groups and communities (Zainal et al., 2019). In line with the research results, empowerment for women provided benefits for developing the WHF members' skills. Kuswanti et al. (2020a) found that women could explore the inseparable relationship between the politics of honor and the politics of representation from the production of academic knowledge.

The research findings suggested that the strategic step of economic empowerment was through the development of savings and loan activities. The output was a savings and loan of primary cooperative as a community-based microfinance institution, while outcome (impact) was of secondary cooperatives as community-based collective financial institutions. Sustainability was community's access and control over financial resources and village financial institutions. Strengthening cooperatives was one of the steps to help mobilize business capital and market products produced by WHF group members' entrepreneurs. 


\section{Implementation of Women's Economic Empowerment Activities through WHF Groups}

The research and FGD results showed that the WHF group activity model cannot be separated from the input, process, output, and outcome. The existence of the group itself was absolute. The assistant was a person, who was assigned from the center to develop one of the branches in the of WHF Union expansion areas. The consistency of the WHF group was also inseparable from the existence of the surrounding environment as a source of input for information and problems related to women's empowerment. Access on information was a very important element to encourage information updates in order to add insight and knowledge in a more global target related to conducting mainstreaming woman's empowerment. Women were a strong deterrent to the state, as stated by (Cetinkaya, 2020), as a voice to demand equal rights, as well as against the prerequisites of their existence as Kurds. 'Mothers of Peace' were constantly reminded of the existence of 'Women' through sexual harassment and violence they faced. Their bodies became places of resistance and domination.

Empowerment through developing non-formal education, which was named Paradigta and the trainings provided to raise the power of thinking for progress, mental improvement and selfconfidence, talent and motivation to be able to fight better in realizing women's economic empowerment and independence in order to fulfil the family needs. The process was conducted by realizing WHF's vision, mission and programs, making a well-thought-out activity plan within one year. The implementation time of the activities was carried out according to the memorandum of agreement. Type of education and training was carried out in accordance to existing curriculum in the work program, education and training program. It was adapted to conditions and problem vulnerability level faced by the group members, and their environment.

The WHF group existed as a forum for solving problems. The initial problem with most WHF members prior to joining the WHF group were unconfident because of some reasons. The first reason was that women were in distress condition due to unprepared becoming widows since their husbands had passed away or they got divorced from their husbands or became victims of domestic violences, feeling helpless, so it was important to strengthen their self-confidences. Moreover, the stigma of society towards widows were negative ones. Secondly, there was no economic readiness after being left by her husband (for example, because initially they were just housewives) so that when she separated from her husband (died or got divorced) she was unprepared, weak, helpless, and had to look for a job. According to Dillard (2020) women participated through their personal experiences and provided social analysis in supporting wider social change through transformational actions from women themselves.

Due to the above mentioned issues, the crucial step WHF groups should take was improving the members' mental status, by among others strengthening and increasing self-confidence, strengthening the economy. Therefore, it was important to carry out education and training in developing skills through mentoring. Once they had already been capable and independent, then slowly the mentors released them without anymore assistanship. Empowerment activity was implemented as a means of forming mental and managerial strength. Improved information both through knowledge provided in education and training, as well as through access on information that could be accessed on the internet related to women's empowerment more broadly. Activities were also very focused on business assistance, which is carried out through the trainings that had been provided. Business development was of course adapted to attractg talent and potential. Its implementation could develop skills for entrepreneurship in order to increase income to fulfil family needs. The research were in line with the results of Andrea's research, saying that creativity was carried out by communicating, cultivating soil, weaving, clay pottery, carrying out affective relationships and implementing communication among humans.

The whole implementation of the program activities certainly could not be separated from supervision. It was to evaluate the activities or programs, whether or not the goal had been achieved, or even delayed in the implementation, or whether it was still on going. The evaluation was very useful to determine the level of achievement or failure in program assessments, which were carried out every year.The education and training activities that had been carried out gave positive outputs for the progress of the WHF group. The reality was that the implementation of these activities could improve WHF members' mentality and increase self-confidence. The FGD results showed that WHF members got stronger because previously their educational backgrounds and low economic status made them lack of self-confidence, but now they are confident, and some are even very confident.

Jurnal Penyuluhan | Vol. 18 (01) 2022 | 129 


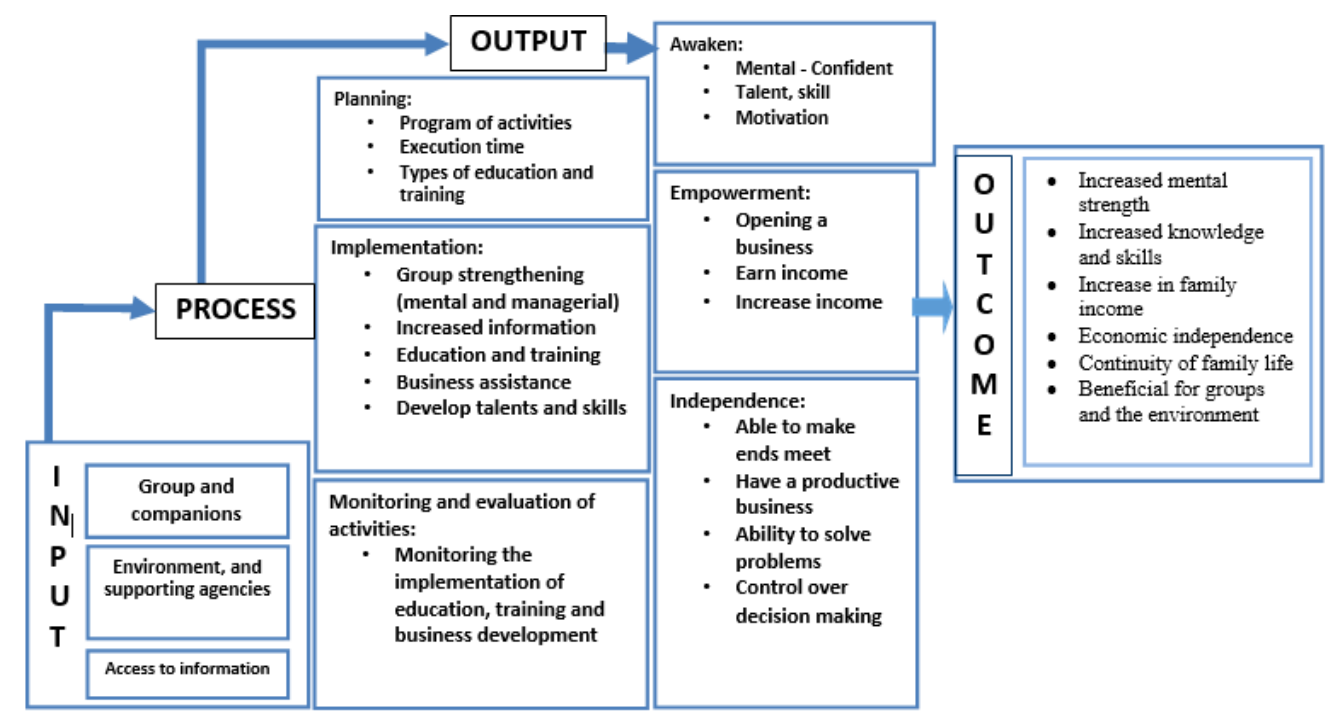

Fig. 4. Woman's economic empowerment activities through WHF groups

The results also showed that WHF members gradually experienced economic empowerment, and had been able to start their own businesses even though they were still on a micro scale. The improved income could realize economic independence. The WHF members found it easier to meet their basic needs (clothing, food, and housing), because they owned productive businesses, so that the economic limitations could be overcome. The positive impact was that it was easier to control decision making in dealing with problems both individually and in groups. The better condition was still being pursued in order to improve their business scale to get better supports for their families.

Outcomes such as improved mental status, better knowledge and skills, higher income, and economic independence could actually be identified, and they were reflected when they appeared at wider scale public forum meetings such as seminar or workshop. They were able to realize economic independence by making the sustainability of a better family life and increasing family economic status. There were some social realities that WHF members, who were successful in developing their skills, knowledge, advance thought, and got more creative and critical in skills, were more beneficial to the group and its environment in dealing with problems in the community as described in Figure 4.

\section{Implications of Women's Economic Empowerment through WHF Groups}

During the communication activity implementation to empower economic independence of the WHF Batang program, it was necessary to assess its weaknesses, strengths and challenges. Mardikanto (2010) and Nugroho (2008) suggested some strategies for community empowerment by improving the scope of family and community life, including access, participation, control and benefits, and it was also important for WHF groups.

The results of FGD showed that there were weaknesses, strengths and challenges in the WHF implementation including: (1) occurrence of drop outs of WHF members and their inactive group; (2) husbands changing their minds and prohibiting their wives from participating in WHF group activities; (3) no confidence; (4) lack of volunteering spirit; (5) and difficulty to manage time because of being busy in working.

There was a contradiction in point three, namely no confidence. In fact WHF program could increase self-confidence and even it made the WHF members become very confident. It was one of the positive impacts of Paradigta education and training, namely through public speaking, journalism, lobbying and negotiation training. The WHF members, who initially did not have self-confidence, being embarrased even to tell their own problems, after joining the WHF group, became women who have confidence. The training begins with learning to speak before a forum, learning to compose sentences, writing stories and life experiences on plenary papers, and then telling it before the fellow members during the training. These activities greatly encouraged the ability to speak, write, and perform persuasively by lobbying and negotiating, especially when carrying out a training activity, workshop or seminar guided by experts as speakers or companions in activities. 
The advantages were as the following: (1) husbands supported all WHF programs; (2) WHF group members were very solid (having high cohesiveness); (3) they were very committed to group activities and had good volunteering spirit. (4) they were good at managing time between work and participating in WHF program activities; (5) the programs could increase self-confidence, even very confident; and (6) they were able to become assistance (advocacy) in handling problems at the police and religious courts, and managing population identity (identity card, birth certificate) and health (health insurance/BPJS, and its card).

The WHF married members were initially permitted by their husbands to participate in all WHF education and training. The condition would be in a dilemma if the husband changed his mind and forbade his wife to take part in WHF activities. The reason was that it took a lot of time to attend WHF education and training. The fact was that it took one week to three weeks in quarantine for a WHF member at one stage of training, while training was usually programmed for up to three months. Based on the length of time required for participation and training, the husband, who lacked a strong commitment, changed his mind so that his wife would leave the WHF membership. However, it was not too significant, only about five to six of the total respondents whose husbands forbade their wives to take part in the WHF program (drop out).

It is well recognized that the kinship systems in our society were mostly patriarchal, but as time goes by, many husbands allow their wives to take part in organizational activities of the community, and their wives took part in earning money for their families. However, only $45 \%$ of husbands genuinely supported their wives to participate in community social institution activities that were facilitated by the WHF groups.

The newest findings in this study were that married women who were included into category of women heads of families because their husbands did not have permanent jobs was $45 \%$, got fired $15 \%$, and jobless 5\%, although the conditions would not be permanent. Based on this and the results of the FGD, it is known that there were several women who were still married but changed roles in supporting the family economy as the main breadwinner. Therefore, there were some married women who shifted their roles from supporting families into the breadwinners, although it was also impermanent.

Existing challenges included: (1) the location of the villages area were far away; (2) villages' officials did not support WHF activities, because they thought that WHF members could become provocateurs in the village (interfering in village affairs), or they demanded transparency of village funds; (3) villages officials were jealous because in the WHF program activities "there was Paradigta education", which was more critical and had better understanding on the Village Act; (4) the village officials did not set Paradigta academy activities as a priority; and (5) the schedule of WHF program activities clashed with the schedule of village activities.

Research findings also showed that village officials appeared to be less supportive towards WHF activities. It seemed that the village officials thought that the WHF group members could become provocateurs in the village (interfering in village affairs), because they demand transparency of village funds use. The Paradigta education activities made WHF more critical, broaden their knowledge, and got better understanding on the Village Act. It made WHF more courageous in voicing their aspirations by demanding transparency of village funds. It also made some village heads be nervous, because not all village heads and officials were transparent on this matter. There were facts that woman's status and role in society were still subordinate, not fully recognized in society as the head of the family, even though WHF played roles as the main decision makers in the families.

\section{CONCLUSION}

The conclusion of the research were as follows: (1) characteristics of WHF members were in the good category, with the highest indicators being in the productive age of 22-43 years; (2) the highest educational attainment score was of elementary education; (3) the highest marital status of WHF members was married; (4) the number of dependents was an average of one to four persons/family; and (5) the income with the highest score was in the range of IDR 500,000-1,000,000 per month (low category).

Around 45 percent of husbands genuinely supported their wives in taking part to earn a living and participating in the activities of community social institutions facilitated by the groups. There were 45 percent of WHF members' husbands had impermanent jobs, 15 percent of the husbands experiencing 
got fired and the other five percent were unemployed. Some WHF members, who were still married switched their roles to be the main breadwinners.

The factors on the economic empowerment variable also showed good results with the indicator of capital access getting the highest average score. Based on the SEM analysis, it could be concluded that the characteristics of WHF members affected economic empowerment. WHF members were able to get economic empowerment through education and training in WHF groups.

The implementation of women's economic empowerment activities through WHF groups could not be separated from the input, process, output, and outcome. The existence of the group itself was absolute. The consistency of the WHF group was also inseparable from the existence of the surrounding environment as a source of inputs for information and problems related to women's empowerment. Access to information was a very important element to encourage information updates in order to add insight and knowledge in a more global target related to mainstreaming women's empowerment.

There were implications for women's economic empowerment activities through WHF groups; however, there was a contradiction with other research result of being unconfident. In contrast, as a positive impact of Paradigta education and training, in fact the WHF members could improve their self-confidence and even become very confident.

\section{ACKNOWLEDGEMENT}

The authors would like extend their gratitude to The Central WHF Program Management, for they have recommended the authors to conduct research in Batang District, Central Java Province. The same gratitude also goes to The WHF Group Members in Batang District, who have become respondents in the study and answered questions in order to complete the research.

\section{REFERENCE}

Bhatia, S., \& Singh, S. (2019). Empowering women through financial inclusion: a study of urban slum. Vikalpa, 44(4), 182-197.

Cetinkaya, H. (2020). Mothers as the middle-ground between the Mountain and the State. Journal of International Women's Studies, 21(7), 207-224.

Chakravarty, D., Feldman, A., \& Penney, E. (2020). Analysing contemporary women's movements for bodily autonomy, pluriversalizing the feminist scholarship on the politics of respectability. Journal of International Women's Studies, 21(7), 170-188.

Cornwall, A. (2016). Women's empowerment: What works? Journal of International Development, $28(3), 342-359$.

Dillard, N. (2020). Designing research to dismantle oppression: Utilizing critical narrative analysis \& critical participatory action research in research on mothering and work and beyond. Journal of International Women's Studies, 21(7), 47-60.

Ghazanfari-Moghaddam, N., \& Sharifimoghaddam, A. (2014). Translating genderism, a way of manipulating gender norms. International Journal of Women's Research, 3(2), 217-240.

Hasan, M., \& Alim, A. (2014). Dilemma and intricacies of law, society and religion towards the empowerment of women in Bangladesh. International Journal of Women's Research, 3(2), 145167.

Hasin, F., \& Musa, H. H. (2018). Women empowerment model: Strategies to overcome challenges research article special issue. Journal of Fundamental and Applied Science, 10, 1068-6083.

Istiyanto B. S., \& Nuryanti. (2013). Kemandirian Ekonomi sebagai Strategi Pemberdayaan Kaum Perempuan di Desa Rejodadi Kecamatan Cimanggu, Cilacap. [prosiding]. Seminar Nasional Penyuluhan dan Pembangunan UGM 1(1):1-9

KunhiSikhaBhuyan, D. (2020). Women empowerment: The role of education in women empowerment. International Journal of Advanced Science and Technology, 29(3), 15451-15456.

Kuswanti, A. \& Oktarina, S. (2019). Pemanfaatan media informasi di era digital bagi kemandirian ibu rumah tangga. Suluh Pembang. J. Ext. Dev, 1(1), 47-55.

Saleh, A., Hubeis, A., Puspitawati, H., Muzykant, V., \& Muqsith, M.A. (2020a). Effect of

Jurnal Penyuluhan | Vol. 18 (01) 2022 | 132 
group participative communication towards pekka economic empowerment. International Journal of Advanced Science and Technology, 29(3), 238-249.

. (2020b).The impact of regulation policy in Indonesia against women's family head. Jurnal Cita Hukum, 8(1), 103-122.

Latifah, D., \& Mulyana, N. (2017). Peran pendamping bagi orang dengan HIV/AIDS (ODHA). Prosiding Penelitian dan Pengabdian Kepada Masyarakat, 2(3).

Mardikanto, T. (2010). Konsep-Konsep Pemberdayaan Masyarakat. Surakarta: Fakultas Pertanian UNS dengan UPT Penerbitan dan Percetakan UNS. UNS Press.

Nagaraja, K. (2018). Empowerment of Women Through Higher Education. International Journal of Current Research, 10(2), 66113-66115.

Nugroho, R. N. (2008). Gender dan Strategi Pengarus-Utamaannya di Indonesia. Jakarta (ID): Pustaka Pelajar.

Porter, E. (2013). Rethinking women's empowerment. Journal of Peacebuilding \& Development, 8(1), $1-14$.

Scheaffer, R. L., Mendenhall III, W., Ott, R. L., \& Gerow, K. G. (2011). Elementary survey sampling. Cengage Learning. Belmont (US): Duxbury Press.

Shabanirad, E., \& Seifi, E. (2014). Postcolonial feminist reading of Khaled Hosseini's A Thousand Splendid Suns. International Journal of Women's Research, 3(2), 241-254.

Suharto, E. (2009). Membangun masyarakat memberdayakan rakyat. Bandung(ID): Refika Aditama.

Sultana, H. Y., Jamal, M. A., \& Najaf, D.E. (2017). Impact of microfinance on women empowerment through poverty alleviation: An assessment of socio-economic conditions in Chennai city of Tamil Nadu. Asian Journal for Poverty Studies (AJPS), 3(2).

Susanti, E., \& Mas' udah, S. (2017). Women's empowerment model in home-based industries in East Java Province, Indonesia. Masyarakat, Kebudayaan Dan Politik, 30(4), 353-366.

Wediawati, B., \& Setiawati, R. (2015). IBM kelompok usaha bersama perempuan kepala keluarga (KUBE-PEKKA) di Kecamatan Telanai Pura Kota Jambi. Jurnal Pengabdian Pada Masyarakat, 30(1), 10-17.

Winther, T., Ulsrud, K., \& Saini, A. (2018). Solar powered electricity access: Implications for women's empowerment in rural Kenya. Energy Research \& Social Science, 44, 61-74.

Yuniriyanti, E., \& Sudarwati, R. (2017). The development model of woman empowerment in order to increase family's food tenacity. Jurnal Ekonomi dan Studi Pembangunan, 9,(1).

Zainal, A.G., Ana Kuswanti, A., Selly Oktarina, S., Andy Corry Wardhani, A., \& Novita Tresiana, N. (2019). A Farm Woman Empowerment Model and Strategy of Communication in an Agropolitan Area at Pesawaran in Ind. This Paper Aims to Know the Empowerment Communication Model and Farm Woman Communication Strategy in Agropolitan Area at Pesawaran. The Study Was Conducted in the District of Gedung Tataan, Pesawaran Using Descriptive Qualitative Method. The Results Show, 14(5). 